\title{
Socio-Environmental Conflicts: A Study on the Logistic Center in Paranapiacaba and Involved Social Representations
}

\author{
Virgínia Hamer Campagnaro \\ Luciana Aparecida Farias \\ Giovano Candiani
}

I Universidade Federal de São Paulo (UNIFESP), Diadema, SP, Brasil.

D II Universidade Federal de São Paulo (UNIFESP), Diadema, SP, Brasil.

D IIl Universidade Federal de São Paulo (UNIFESP), Diadema, SP, Brasil.

\begin{abstract}
Socio-environmental conflicts have been intensifying in the 21st century, which has prompted new approaches seeking to identify the origin of these conflicts and enrich their analyses. This study monitored the environmental licensing of the Campo Grande Logistic Center, in Paranapiacaba, a district in Santo André (SP), in order to identify the social representations of the environment for different actors involved in the licensing process and discuss the interference of the social representations in the established conflict. The case study employed multiple methods of data collection, including participant observation, semi-structured interviews, and document analysis. A prototypical analysis was carried out in line with the theory of social representations by Moscovici, Abric, and Reigota's environment classification. The social representations found were globalizing for civil society and anthropocentric for the entrepreneur, relating the origin of the conflict to different material and symbolic appropriations of environmental resources, in this case, the territory itself.
\end{abstract}

Keywords: Socio-environmental Conflict; Social Representations; Paranapiacaba; Public Participation; Environmental Licensing.

São Paulo. Vol. 24, 2021

Original Article

DOI: http://dx.doi.org/10.1590/1809-4422asoc20200212r1vu2021L4AO 


\section{Introduction}

Environmental licensing is one of the main environmental planning instruments in the country; it involves decision-making about ventures with potential to cause significant environmental impact. These decision-making processes comprise a series of complex issues to be taken into account, as well as bring along a large set of factors and social actors - each of them has its own immeasurable and incomparable weight. Thus, public participation in environmental licensing processes is associated with better decision-making, which it is also an essential right to democratic societies (GLUNCKER et al., 2013).

It is crucial investigating how environmental licensing processes take place in order to help better understanding the aims of each social actor involved, as well as to find out who these actors are and what social representations of "environment" and "sustainability" are linked to the investigated territory (SANTOS \& CHESS, 2003). Since environmental licensing is a decision-making process concerning environmental resources, it can lead to different socio-environmental conflicts or bring pre-existing conflicts to light (BERNARDELLI JÚNIOR; RUIZ; GALLARDO, 2017; SOARES; OLIVEIRA; FONSECA, 2015; TORRES; RAMOS; GONÇALVES, 2019), since they derive from different environmental resource use and significance projects (ACSELRAD, 2004). On the other hand, previous studies have shown that conflicts can often be influenced by efficient communication processes (GHOZ et al., 2020), but it is essential having prior knowledge about the origins of the conflict, as well as about the conflict itself and about what is in dispute for communication to be effective. Therefore, it is necessary deeply understanding these issues in order to investigate the meaning given to the "environment" by each involved party.

There is no consensus about the meaning of the term "environment", not even among scholars, since it may involve physical and biological aspects, sociocultural issues, or even comprise naive and naturalistic viewpoints (REIGOTA, 2002). Therefore, studies based on the theoretical concept of social representations have emerged as important resource to help better understanding socio-environmental conflicts (BACIC et al., 2017; FLEURY; ALMEIDA, 2009; ROSA, 2014). In most cases, they aim at investigating the meaning of "environment" that has been used and at reflecting about what it implies (REIGOTA, 2002). This new perspective sheds light on aspects that remain little observed in environmental licensing case studies.

Thus, this theoretical framework can be an important tool in environmental licensing studies, since the concept of environment is featured as social representation, i.e., the common-sense representation attributed by individuals to prejudice, ideologies, and personal meanings (JODELET, 2001; MOSCOVICI, 1978). The herein conducted analysis was based on the social representation of the environment as essential factor to understand socio-environmental conflicts observed in the research site.

It is worth highlighting that three different theoretical currents associated with the study about social representations have emerged from Moscovici's initial theory. Among them, one finds the structural approach by Abric (1993), also known as Central Core 
Theory. According to it, social representations can be divided into two different systems, namely: the central core, which accounts for attributing basic meaning to social representation within a given group by reflecting its socio-historical conditions and values, and by being more stable; and the peripheral system, which accounts for connecting the central core to the concrete reality by covering individual histories, group heterogeneities and, therefore, by being more changeable (SÁ, 1996). This approach has gained great prominence in studies conducted in the most diverse knowledge fields; it became known as prototypical analysis (WOLTER et al., 2009).

Based on this perspective, the aim of the current study was to monitor Campo Grande Logistic Center's environmental licensing process, in Paranapiacaba District, Santo André County (SP), in order to identify the social environmental representation of different actors involved in this process and to evaluate their likely interferences in the herein observed socio-environmental conflict between 2018 and 2019.

\section{Study Site}

Paranapiacaba is a district of Santo André County, where Paranapiacaba Village is located in, and its origin is associated with Santos-Jundiaí Railroad. The aforementioned district accounts for connecting the Metropolitan Region of São Paulo (RMSP) to Santos Port. The site has extensive Atlantic Forest remnants, which host several Conservation Units; it was declared Green Belt Biosphere Reserve by UNESCO (TORRES; RAMOS; GONÇALVES, 2019) and is included in the county's Environmental Protection Macrozone (which belongs to RMSP), in Serra do Mar region.

The Village region and the railway are listed at federal, state and municipal levels, due to their historical and tourist importance. The city hall has bought Paranapiacaba Village in 2002 to develop sustainable tourism in the region and to promote its socio-economic development (NETO, 2005). Despite having achieved socio-economical improvements, mainly through tourism development, the local population still deals with low-income levels and faces health, education and infrastructure precariousness, a fact that leads to population reduction on a yearly basis (COLANTUONO; CESTARO, 2017).

The socio-environmental conflict investigated in the current article is associated with land-use planning in the region, which is materialized through Campo Grande Logistic Center's environmental licensing, that started in 2016 but only became public in 2018, after a public hearing was scheduled. From this moment, the undertaking generated mobilization from groups opposed to it, both due to expected high environmental impact and to suspicions about irregularities in the licensing process (TORRES; RAMOS; GONÇALVES, 2019). The proposed venture is currently under analysis to obtain the Prior License issued by the Environmental Company of São Paulo State (CETESB). It consists in a "condominium designed to house cargo redistribution activities, by using adjacent railways and highways to transport the cargo to its destination" (CPEA, 2017b, p. 6). It is distributed over three plots located on the margins of Santos-Jundiaí railroad, in Campo Grande neighborhood and in Paranapiacaba district. The development's total area covers 468.26 hectares according to the original project, which is described in the 
environmental impact statement (EIS), and 91 hectares of this total would be effectively occupied. Based on Figure 1, it is possible seeing the proximity between the venture and Paranapiacaba Village.

Figure 1 - Delimitation of Campo Grande Logistic Center area.

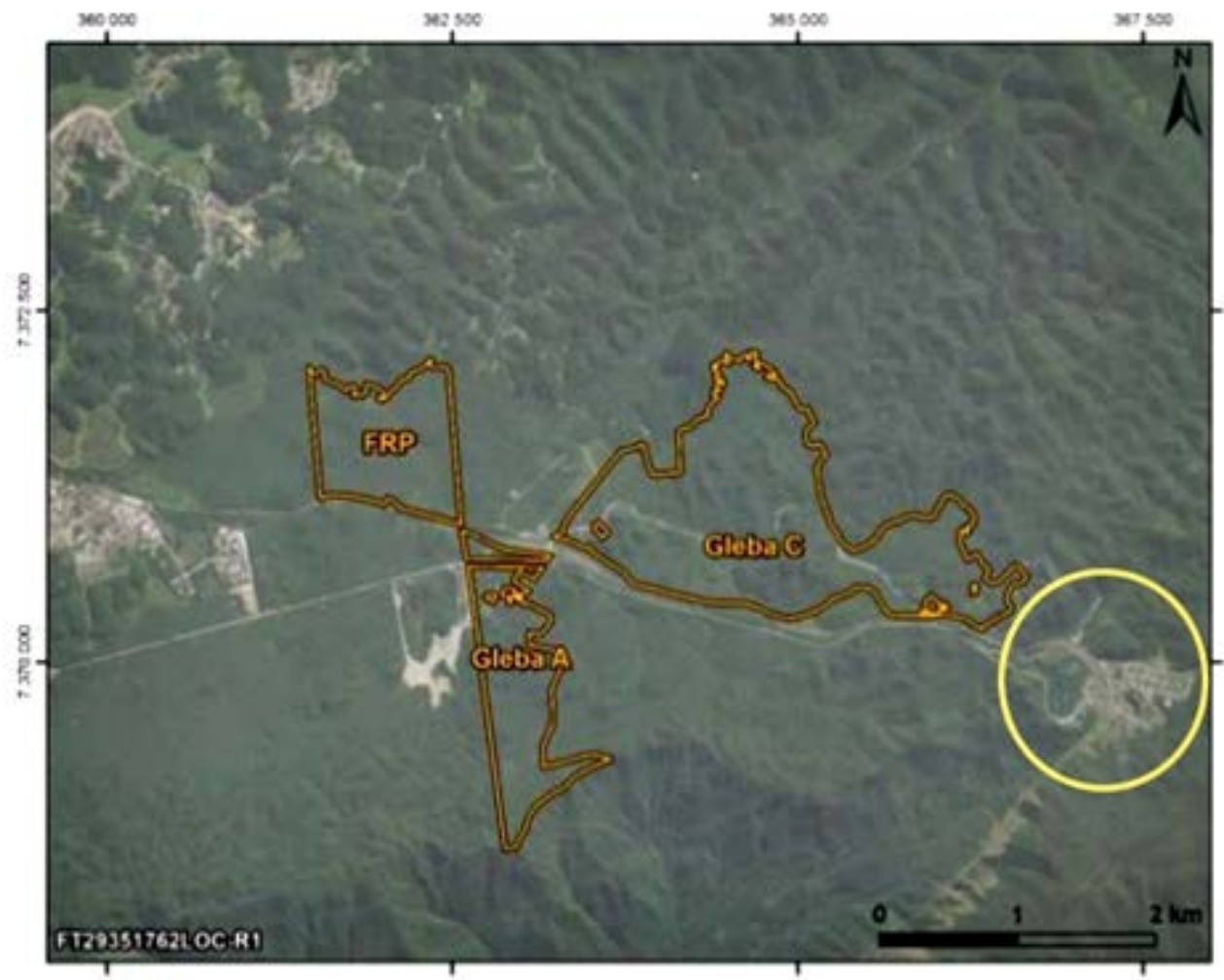

Key

$\square$ Directly affected area

Paranapiacaba Village

Source: Adapted from EIS (CPEA, 2017a, p. 86).

\section{Methods}

The current research is a mixed case study (qualitative and quantitative) (CRESWELL, 2010). The option for using the case study methodology was justified by the aim of better understanding a highly complex and relevant licensing process in order to investigate the environmental licensing taking place in São Paulo State. This process has generated popular mobilizations, as well as involved the local media and the Public Prosecutor's Office (MELO, 2019; TOSSATO, 2021). Data were collected through triangulation process (CRESWELL, 2010) by using participant observation, document 
analysis and structured interviews as collection methods.

Participant observation was carried out from March 2018 to February 2019, after a former Paranapiacaba Village resident reported the incidence of the first events. The aim of this procedure was to feature the actors involved in the events and to establish the main conflict points. It consisted in monitoring 25 meetings - e.g., public hearings, meetings among different actors, academic workshops, and public demonstrations - associated with public participation in the environmental licensing process. The monitoring process was carried out based on audio recording and on notes written in field journal.

The analyzed documents about the licensing process were obtained through the CETESB system, at the E-ambiente portal (https://e.ambiente.sp.gov.br/atendimento/), whereas manifests and flyers were provided by the SOS Paranapiacaba movement. Document analysis was based on categories established by Reigota (2002), for social representations applied to the term "environment".

The word association task was used for interviews, since it allows identifying social representations that do not always appear in descriptions and personal reports. This test is widely used in Social Psychology because of its spontaneity, as well as because it makes prototypical analysis easier and enables identifying the core of representations (SÁ, 1996). The test was applied to 42 participants, who were asked to name five words that came to mind when they heard the inductive terms "environment" and "sustainability", which were selected for being polysemic terms linked to licensing; and to elaborate a sentence using the quoted words. Data such as sex, age, profession, schooling, mean wage, and place of residence were also collected. All interviews were audio-recorded, under interviewees' consent, who signed the Informed Consent Form (Report CEP/UNIFESP 2.795.790); subsequently, they were fully transcribed and categorized based on Reigota (2002). Words evoked by the inductor term were grouped based on semantic criteria and analyzed in Excel software adapted from the EVOC 2000 software, created by Pierre Vergé. This software categorizes the evoked words, calculates the frequency and mean order of evocations, and investigates the centrality of representation elements based on the four-quadrant frame: central core, contrast zone, first and second peripheral systems (PEREZ, 2008). Thus, interviews were analyzed, results recorded for different groups were compared to each other and social representations' centrality was discussed.

Representative categories used for content analysis (both from document analysis and from interviews) were pre-selected, based on categories elaborated by Reigota (2002) - who is an important reference in the field - and compared to those of other studies. The categories are: naturalist, in which the environment is seen based on its natural aspects, such as physical-chemical and biological aspects, although it does not include social aspects - humans are just external observers; anthropocentric, in which the environment is seen only as natural resource and do not take into consideration the society, but unlike the naturalist view, the environment is seen as resource to support human beings; globalizing, in which the environment is featured by relationships between nature and society, which include social, political, economic and cultural aspects, as well as the natural ones. 


\section{Results and Discussion}

Campo Grande Logistic Center's environmental licensing is the main target of the herein investigated socio-environmental conflict. Participant Observation was carried out at the first stage of the study; it was done to help better understanding the social actors involved in this conflict and to establish the main points involved in it. In order to do so, it was necessary participating in several licensing-related events. Three main groups were identified among the aforementioned actors: entrepreneur, government and civil society, as highlighted in Table 1.

Table 1 - Featuring the main social actors.

\begin{tabular}{|l|l|l|}
\hline \multicolumn{2}{|l|}{ Actors } & Description \\
\hline \multirow{5}{*}{ Entrepreneur } & $\begin{array}{l}\text { Fazenda Campo Grande } \\
\text { Empreendimentos e Partici- } \\
\text { pações Ltda. }\end{array}$ & $\begin{array}{l}\text { The company proposing the venture and } \\
\text { pursuing its environmental licensing. It } \\
\text { defends its installation as necessary to } \\
\text { expand the operationalization of the car- } \\
\text { go transport capacity by rail network in } \\
\text { the Metropolitan Region of São Paulo. }\end{array}$ \\
\cline { 2 - 3 } & $\begin{array}{l}\text { Consultoria, Planejamento } \\
\text { e Estudos Ambientais Ltda. } \\
\text { (CPEA) }\end{array}$ & $\begin{array}{l}\text { Consultancy company accounting for } \\
\text { preparing environmental studies. }\end{array}$ \\
\hline
\end{tabular}




\begin{tabular}{|c|c|c|}
\hline & $\begin{array}{l}\text { São Paulo State Environmen- } \\
\text { tal Company (CETESB) }\end{array}$ & $\begin{array}{l}\text { The agency accounts for evaluating the } \\
\text { project and for deciding on whether to } \\
\text { grant the environmental license, or not. }\end{array}$ \\
\hline & $\begin{array}{l}\text { State Council for the Envi- } \\
\text { ronment (CONSEMA) }\end{array}$ & $\begin{array}{l}\text { The agency accounts for convening and } \\
\text { conducting public hearings, in addition } \\
\text { to having consultative and regulatory } \\
\text { attributions indirectly related to the } \\
\text { venture. }\end{array}$ \\
\hline & $\begin{array}{l}\text { Municipal Secretariat for the } \\
\text { Environment (SMMA) }\end{array}$ & $\begin{array}{l}\text { It manages the territory where the } \\
\text { venture would be implemented in. It } \\
\text { accounts for issuing a technical report } \\
\text { on the venture (non-binding). }\end{array}$ \\
\hline \multirow[t]{3}{*}{ Public Power } & Municipal Councils & $\begin{array}{l}\text { They act, either directly or indirectly, } \\
\text { in licensing, by issuing opinions and } \\
\text { approving municipal legislations. The } \\
\text { main councils comprise the Municipal } \\
\text { Council for the Defense of the Histori- } \\
\text { cal, Artistic, Architectural-Urbanistic } \\
\text { and Landscape Heritage of Santo } \\
\text { André (COMDEPHAAPASA) and the } \\
\text { Municipal Council for the Management } \\
\text { and Environmental Sanitation of Santo } \\
\text { André (COMUGESAN). }\end{array}$ \\
\hline & Santo André City Hall & $\begin{array}{l}\text { It accounts for issuing documents ne- } \\
\text { cessary for the progress of the licensing } \\
\text { process, such as the land use certificate. }\end{array}$ \\
\hline & $\begin{array}{l}\text { Public Prosecutor's Office } \\
\text { (state level) }\end{array}$ & $\begin{array}{l}\text { It operates through independent law- } \\
\text { suits. }\end{array}$ \\
\hline
\end{tabular}




\begin{tabular}{|c|c|c|}
\hline \multirow{3}{*}{ Civil society } & SOS Paranapiacaba & $\begin{array}{l}\text { Movement opposed to the implemen- } \\
\text { tation of the venture; it comprises civil } \\
\text { associations, universities, members of } \\
\text { political parties and the region's resi- } \\
\text { dents, who advocate that the venture } \\
\text { must be stopped due to its environmen- } \\
\text { tal and social impacts, and to irregulari- } \\
\text { ties in the licensing process. }\end{array}$ \\
\hline & Paranapiacaba inhabitants & $\begin{array}{l}\text { Residents living in Paranapiacaba dis- } \\
\text { trict, who do not constitute a homoge- } \\
\text { neous group. There are individuals who } \\
\text { act against the environmental license, } \\
\text { because they believe that the develo- } \\
\text { pment will bring losses to the region, } \\
\text { whereas others act in favor of it, because } \\
\text { they believe it will bring improvements } \\
\text { to the region. }\end{array}$ \\
\hline & Universities & $\begin{array}{l}\text { Professors and students from universities } \\
\text { in the region who helped preparing tech- } \\
\text { nical documents and scientific articles } \\
\text { on the subject. }\end{array}$ \\
\hline
\end{tabular}

Source: Prepared by the authors.

It is noteworthy that, except for the entrepreneur group, different actors in each group did not necessarily have the same views or interests about the venture. For example, some public authorities manifested themselves against it. Among them, one finds the Public Prosecutor's Office, which issued an opinion against the license issuance, whereas others, such as CETESB, tried not to express their position and decides to wait for the procedural licensing rite to be concluded and requested likely additions to the studies.

SOS Paranapiacaba was the group presenting the strongest public participation in the environmental licensing process. It is a movement of horizontal organization with no official leadership. The group has mobilized through meetings held face-to-face and on social media such as Facebook and WhatsApp. It presents heterogeneous composition, which comprises individuals at different age groups, social classes, municipalities, schooling and backgrounds, a fact that enables a wide variety of perspectives and viewpoints. Given its large number of members, visions and experiences, it is relevant analyzing these members' social representations around two central topics in the conflict, namely: "environment" and "sustainability". 


\section{Social Representations of Active Civil Society in the Licensing Process}

Forty-two (42) individuals divided into two groups were interviewed, namely: 25 environmentalists from SOS Paranapiacaba, who did not live in the region, and 17 individuals from Paranapiacaba region (some of them were environmentalist-group members, whereas others were not); among them, 14 lived in the region and 3 lived elsewhere, although they had previously lived and/or worked in Paranapiacaba Village and had close relationship with the region.

Male and female participants' distribution in both groups was balanced, whereas the distribution based on age group presented prevalence of individuals in the age group 40-59 years, and smaller number of young and elderly individuals. The group of environmentalists presented higher schooling than the Paranapiacaba residents' group; however, overall, most participants had complete or incomplete higher education.

With respect to the word-association task, 200 evocations were recorded for each term. Based on the semantic analysis, 105 different words were recorded for "environment", whereas 139 words were associated with "sustainability". Social representation diagrams were generated based on the aforementioned analysis. Table 2 shows diagrams generated for social representations obtained for inductive terms "environment" and "sustainability" in the environmentalists' group.

Table 2 - Diagram presenting structures observed for environmentalists' social representations. $(n=25)$

\begin{tabular}{|c|c|c|c|c|c|c|}
\hline & \multicolumn{6}{|c|}{ Inductive term "Environment" } \\
\hline \multirow{5}{*}{ 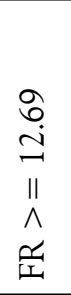 } & \multicolumn{3}{|c|}{$\mathrm{AEO}<2.95$} & \multicolumn{3}{|l|}{$\mathrm{AEO}>=2.95$} \\
\hline & \multicolumn{3}{|l|}{ Central Core (CC) } & \multicolumn{3}{|c|}{ First Periphery (FP) } \\
\hline & & Freq & & & Freq & OME \\
\hline & Nature & 27 & 2.56 & Quality of life & 15 & 3.67 \\
\hline & Sustainable development & 20 & 2.8 & Resources & 14 & 3.50 \\
\hline \multirow{8}{*}{$\begin{array}{l}\text { oे } \\
\text { ป } \\
\text { v } \\
\text { 品 }\end{array}$} & \multicolumn{3}{|l|}{ Contrast Zone (CZ) } & \multicolumn{3}{|c|}{ Second Periphery (SP) } \\
\hline & & Freq & & & Freq & OME \\
\hline & Integration & 9 & 2.33 & Education & 9 & 3.33 \\
\hline & Citizenship & 5 & 2.00 & Conservation & 8 & 3.38 \\
\hline & Cultural Elements & 4 & 1.75 & Degradation & 6 & 4.17 \\
\hline & \multicolumn{6}{|c|}{ Inductive term "Sustainability" } \\
\hline & \multicolumn{3}{|c|}{$\mathrm{AEO}<3.09$} & \multicolumn{3}{|l|}{$\mathrm{AEO}>=3.09$} \\
\hline & \multicolumn{3}{|l|}{ Central Core (CC) } & \multicolumn{3}{|c|}{ First Periphery (FP) } \\
\hline
\end{tabular}




\begin{tabular}{|c|c|c|c|c|c|c|}
\hline \multirow{5}{*}{ 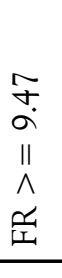 } & & Freq & & & Freq & $\mathrm{OME}$ \\
\hline & Waste & 19 & 2.47 & Resources & 10 & 3.20 \\
\hline & Ecological balance & 13 & 3.00 & & & \\
\hline & Nature & 12 & 2.58 & & & \\
\hline & Sustainable development & 12 & 2.47 & & & \\
\hline & Contrast Zone (CZ) & & & Second Periphery (SP) & & \\
\hline \multirow{6}{*}{$\begin{array}{l}\text { テे } \\
\stackrel{a}{ } \\
\text { v } \\
\text { 岌 }\end{array}$} & & Freq & & & Freq & $\mathrm{OME}$ \\
\hline & Society & 8 & 3.00 & False speech & 9 & 3.44 \\
\hline & Exploration & 8 & 2.88 & Economic development & 6 & 3.17 \\
\hline & Quality of life & 2 & 3.00 & Conservation & 5 & 3.80 \\
\hline & & & & Human Rights & 5 & 3.80 \\
\hline & & & & Education & 5 & 3.40 \\
\hline
\end{tabular}

Caption: Freq: evocation frequencies and AEO: average evocation order. Source: Elaborated by the authors.

With respect to the term "environment", the group of environmentalists presented terms such as Nature and Sustainable Development as the likely central core of the social representation - these two terms were the most readily mentioned elements, as well as the most frequent ones. The presence of both terms has indicated comprehensive view about the topic, which was not limited to natural aspects and took into consideration social and environmental aspects. The contrast zone represents the terms less frequently evoked and often opposed to the first quadrant; it is very important to represent likely subgroups presenting different social representation. In this case, terms such as Citizenship, Integration, and Cultural Elements have emerged, and it may be associated with individuals who see the environment as heritage and as part of democratic societies.

The first and second peripheries represent elements that were not yet incorporated to the central core, but that were most recently incorporated to social representation as a whole. They are the quadrants mostly susceptible to changes after interventions or lectures, for example. Terms such as Quality of Life, Resources, Education, and Conservation have also indicated a more complex view about the environment, which encompassed natural and social aspects. The incidence of element Degradation may be associated with the way the group sees the environment being constantly threatened, a fact that may be related to their motivation to participate in the licensing process.

As for the term "sustainability", the likely central core has also correlated natural elements (such as Environment and Ecological Balance) to social elements (such as Sustainable Development and Waste). Some elements in the peripheral zones and in the contrast zone have indicated negative view about the concept of Sustainability, which was considered by some interviewees as "false" due to the way the term has been used in the business environment (LOUREIRO; LIMA, 2012). However, there were also positive views, which placed society as transforming element based on education, as well as on 
the need of conserving the environment and its resources.

Table 3 shows diagrams generated for social representations obtained for inductive terms "environment" and "sustainability" in the group of Paranapiacaba residents.

Table 3 - Diagram presenting structures observed for social representations of Paranapiacaba residents. $(n=17)$

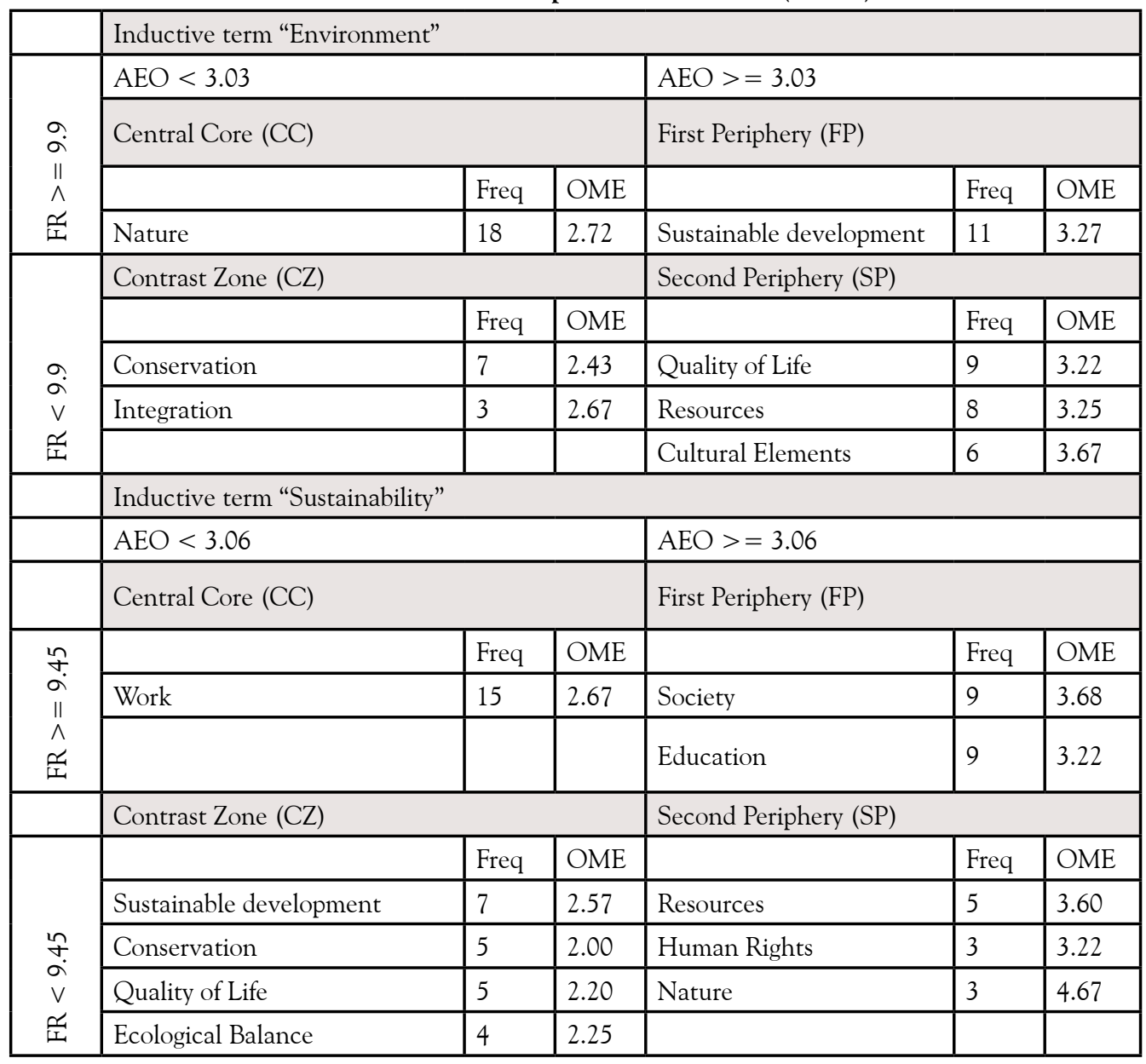

Caption: Freq: evocation frequencies and AEO: average evocation order. Source: Elaborated by the authors.

With respect to the term "environment", Paranapiacaba residents have also mentioned Nature as likely central-core component, whereas Sustainable Development was mentioned as part of the first periphery; this term was recently incorporated to this group's representation, likely due to recent regional development. Terms Integration and Conservation in the contrast zone can be associated with some individuals who consider it as priority because it is part of their work (as in the case of environmental monitors) 
and who have a more integrated perspective about the environment. Environment representation of this group has also presented a set of natural and socio-environmental elements - social elements were mostly observed in the second periphery (Quality of Life and Cultural Elements).

As for the term "sustainability", the only element identified for the likely central core - i.e., Work - was associated with the way these individuals see their lifestyle, since many residents in the village work with sustainable tourism and value the region's historical and environmental heritage. Peripheral areas presented elements associated with the local community, as well as with the historical heritage of and natural elements in the region.

Both groups presented a set of natural and social elements in their representation, and it indicated a perspective that humans are part of the environment and depend on it. The presence of social elements displaced from the central core in the group of $\mathrm{Pa}$ ranapiacaba residents may represent a more naturalistic view, which has been changing and including human elements in recent times. Nevertheless, both groups presented a social representation of the environment that could be considered globalizing, based on categories set by Reigota (2002). It was possible noticing different views within this group (and it was expected due to its heterogeneity), wherein some members mostly value the natural aspects, whereas others value the social ones; some are more critical, whereas others are more superficial. However, they overall understand the different environmental components interacting with each other, and acknowledge humans' inclusion in nature as entities capable of performing and undergoing changes. This richness of perspectives may have contributed to popular mobilization concerning the venture, since they complete each other and converge into a shared goal, which lies on preventing its environmental licensing from happening.

By comparing the current results to those of other studies focused on investigating social representations of the environment, there is clear evidence of a common discourse about the need of taking care of and protecting nature (NASCIMENTO-SCHÜLZE, 2000; POLLI; KUHNEN, 2011). According to Silva (2009), naturalistic and anthropocentric views of the environment prevail in studies conducted in Brazil in this knowledge field. Results observed for both herein investigated groups - i.e., environmentalists and Paranapiacaba residents - differed from the scenario identified by the aforementioned author, since it identified a globalizing perspective that includes humans as integral part of the environment and that takes into consideration its complexity.

Paranapiacaba Village has experienced a participatory management period from 2001 to 2008, after Paranapiacaba and Parque Andreense Subprefecture (which was extinct after this period) was launched. The subprefecture have developed a series of actions, policies, and programs aimed at developing the local community to enable sustainable tourism, education, and cultural and natural heritage conservation (FIGUEIREDO, 2011). Although this management no longer exists, social representations resulting from it can be indicative of positive results left by its actions, as well as a way of explaining the results recorded for this group.

Souza Filho and Durandegui (2002) have evaluated representations of the envi- 
ronment among NGO ecologists in Brazil. Although they identified a wide diversity of lines of thought, they also observed a nature idealization that disregards society's inclusion, which is a factor seen as negative element. Difficulties in social dialogue were also identified, such as lack of validity to other groups and cultures.

The herein investigated environmentalists presented a different perspective, since although the Degradation element emerged with negative connotation - associated with human activities on nature -, other social elements were also included in the representation of the environment, such as Cultural Elements, Citizenship, and Education, in addition to Sustainable Development, which was observed in the likely central core encompassing the social sphere.

The term "sustainability", by itself, has polysemic nature, since it encompasses different meanings and variables, as well as unifies environmental, economic and social issues, among others. It may be the reason why its social representation has not been much investigated in the literature and its approach is mostly focused on groups comprising higher education students (MATOS et al., 2012; RAMOS; KAWAMURA, 2009; TE$\mathrm{CHIO}$ et al., 2016). These studies presented different results, identifying anthropocentric (RAMOS; KAWAMURA, 2009) and naturalistic views (MATOS et al., 2012). Most recent studies identified sustainability representations grounded in the environmental issue, although they also included socioeconomic dimensions in most peripheral zones (TECHIO et al., 2016) - this result is closer to the ones obtained in the current case study.

\section{Social Representations Obtained Through Document Analysis}

Documents prepared by two of the main groups of social actors (civil society and entrepreneurs) involved in the conflict were evaluated to collect data on the social representation of the environment.

\section{Documents prepared by civil society}

a) Letter from Paranapiacaba: the letter was written by the environmental movement to be read in an act in defense of Paranapiacaba heritage; it addresses different topics associated with the region, such as its history and the importance of its environmental and cultural heritage. Traditional communities are also mentioned due to their valuable knowledge and lifestyle; Earth is idealized as "mother-provider". Excerpts from the Earth Charter are cited to advocated for environmental resources' conservation and to promote sustainable societies. The Logistic Center is mentioned at several points; it is called "Dry Port" and categorized as threat to the region; the letter mentions impacts expected to result from its construction, mainly the high circulation of trucks. The text ends by calling readers to form an Earth protection alliance.

Based on categories defined by Reigota (2002), the letter presents excerpts with globalizing representation features, since it correlates the Logistic Center's impact on natural and cultural heritage in an integrated and complex way, as well as presents the environment as historically built through interaction with human beings, as shown in 
the following example:

In the Atlantic Forest (Dense Ombrophilous Forest), where Campo Grande and Paranapiacaba are located in, there is an intimate relationship among forests, rain, water production, biodiversity, and sustainable tourism. [...]

Some excerpts present a naturalistic perspective, since the environment is described as "mother-provider" who must be protected from human greed, in an apparent attempt to sensitize the interlocutor, as shown in the following excerpt:

[...] We are children of the earth, not the oldest or the best, just another species in this Mother Earth, which generously shelters us in its entrails. Therefore, protecting the Earth's vitality, diversity and beauty is our sacred duty.

b) Manifest of environmental monitors: document signed by the Association of Environmental Monitors (AEM) of Paranapiacaba Village, to manifest against the venture. Initially, it presents data about Paranapiacaba Village and its trajectory over the last 20 years, it also values sustainable tourism through environmental monitoring. Then, Campo Grande Logistic Center is presented as threat to everything that has been developed in this regard. The expected impacts from its construction are listed and the EIS is criticized, both for omissions and for its results. This view makes it clear that the venture does not reflect the regions' real vocation, namely: sustainable tourism and conservation, as shown in the following excerpt:

We affirm that Campo Grande Logistic Center is not an activity converging towards the Paranapiacaba development policy; [...] Environmental monitoring is fully compatible to the historical, cultural, natural, and human heritage of Paranapiacaba.

When mentioning the likely impacts deriving from the implementation of the venture, different environmental aspects and their interaction are correlated, which reflects the group's understanding about environmental complexity. According to the categories defined by Reigota (2002), the globalizing representation prevails in the document; this finding may be associated with monitors' training and professional performance, as well as with the fact that they live in a place valued for its environmental heritage.

c) SOS Paranapiacaba brochure: brochure prepared by the movement to be handed out in actions against the Logistic Center, during the Winter Festival, which is an important tourist event that takes place in the village, in July. Its purpose is to inform the public about the venture and its impacts, as well as to promote the movement against it. It presents images of Paranapiacaba Village and public acts promoted by the movement; its text presents the summary of what the Logistic Center would be, its main impacts, as well as information on tourism in Paranapiacaba. Finally, there is a link to the petition against the venture and to the movement's Facebook page. There is an excerpt from the 
brochure that highlights the importance of social participation and invites the public to mobilize itself against the venture, to take a stand on social networks, to monitor its progress, and to participate in public hearings.

As for the social representations of the environment (REIGOTA, 2002), globalizing representation was identified in the text; it integrated tourism, natural and cultural patrimony, and highlighted the importance of Paranapiacaba conservation for the region, which was symbolized by a photo integrating historical heritage, tourism and Serra do Mar.

\section{Documents prepared by the entrepreneur}

a) Brochure presenting the summary of Campo Grande Logistic Center venture: brochure handed out at the beginning of the venture's publicity campaign, had magazine format and provided the most relevant information about it. The brochure described the Logistic Center project, justified its construction, showed the place where it would be built, its benefits and environmental programs, but it did not mention any negative impact caused by it. The environmental issue was rarely mentioned, the document was mostly limited to the location of the venture and to environmental programs. The environment is only represented in its physical and biological aspects throughout the text, humans are not included it in, a fact that categorizes the text as anthropocentric representation (REIGOTA, 2002).

b) Brochures handed out at public hearings: overall, the brochure summarized different information about the Logistic Center, such as what it would be, its location, its goal and positive impacts; however, data presented by it diverged from those observed in the EIS and in the previously delivered brochure. Although the venture was defined as intermodal platform linking the railroad to the highway, there is a speech claiming it as railroader, due to criticisms made by the environmental movement about trucks' circulation. Public hearings schedules and places are mentioned in a short excerpt; these hearings are understood as the place to get to know the venture, rather than for debates or contestations ("come and find out more about the venture").

The anthropocentric representation (REIGOTA, 2002) was identified in the document, since it did not include humans as part of the environment and focused more on the need of transforming the area than on the likely negative impacts that will be assumingly caused by the venture, which are not even mentioned. The document also suggested that areas that would not host the venture's structures would not undergo "interventions" (term used to replace "impacts"), and it showed lack of integrated vision among different aspects (natural, social, economic, among others). In addition, the term "environment" - when it was used - appeared along with "preservation", which featured a conceptual mistake, since the term is inappropriate for the case; "conservation" is more appropriate, since the construction of the venture necessarily implies changes in the area.

c) EIS/EIR: we made the option for analyzing the environmental impact report 
(EIR), because it is a summary prepared to be accessed by the population, which provides information considered by the consultancy as the most relevant to help the public to better understand the project. Despite its technical nature, biases were identified in the approach to environmental issues due to the way it portrays the area as a source of resources to be explored. Environmental impacts are superficially approached, cumulative impacts are disregarded, as well as negative social impacts. Emphasis is given on socio-economic impacts seen as positive in order to justify the need of implementing the venture. Among the main impacts, there is none associated with the local population; the only impact associated with socioeconomic environment lies on the "consolidation of the intermodal logistical vocation", which is considered positive. Therefore, the document presents reductionist ideas about the environment and does not satisfactorily address the social dimension and interactions between biological and physical-chemical aspects, thus it features an anthropocentric representation (REIGOTA, 2002).

In summary, the prevalent representations observed in the documents prepared by the environmental movement comprised the globalizing representation, which was found in all documents. It was followed by the naturalist representation, which was found in one of the documents. Documents prepared by the entrepreneur have only presented anthropocentric representation.

Overall, the main difference observed among social actors was the fact that the entrepreneur does not consider the environment dynamic, since its components interact with each other; in addition, it does not take into account social issues, which are a component valued by the environmental movement. Both groups see potential in the area; however, according to the entrepreneur, this potential is associated with the economic exploitation of both the railway and highway, whereas according to the environmental movement, this potential is associated with the conservation of the area and with tourism sustainable development. By correlating the different representations observed in the current study to the socio-environmental conflict in question, it is possible noticing that, although social actors attributed different meanings to the environment, their views were not necessarily antagonistic, and it enabled overcoming the view that the conflict is limited to "preservationists" versus "developmentalists". The agenda lies on different views on the appropriation of environmental resources - in this case, the resource would be the territory, both in its material condition and symbolic meaning, which is associated with actors' affectivity and subjectivity (ACSELRAD, 2004); thus, it can be considered a conflict over territory. According to Westman (1985), conflicts can emerge from lack of adequate understanding about the costs, benefits, and environmental risks in the proposition of different actions. This statement applies to the current case study due to the anthropocentric view identified by the entrepreneur, who does not take into consideration the complexity of environmental impacts generated by his venture.

Based on these different views, which represent different material world development and appropriation forms, there is no right or wrong. However, it is necessary questioning what interests each vision will be serving to and who benefits from each model (BRONZ, 2016). Economic growth benefits the group that owns the area, whereas tourism 
sustainable development and Atlantic Forest conservation benefits the entire community. In addition, before any likely perspective about the area's potential, it is essential respecting the legislation, which establishes its use to enable sustainable development and environmental resources' conservation. The environmental issue must be included in regional planning, which currently privileges large private capital ventures (TORRES; RAMOS; GONÇALVES, 2019).

As the current case study refers to an environmental licensing yet in progress, it would still be possible solving the conflict through dialogue between the involved parties, and ultimately, through its judicialization, as it is already happening (TOSSATO, 2021). If the differences among actors had been identified at the beginning of the process, the conflict could have been anticipated and likely solutions could have been found (WESTMAN, 1985). Thus, the study of social representations has proved to be a valuable tool to solve conflicts at their early stages, when agreements between parties can be more easily reached.

\section{Final Considerations}

This case study has evidenced socio-environmental conflict generated by different visions about the environment and by expectations arising from the proposition of a venture, towards the development of the investigated area. The entrepreneur presented an anthropocentric representation of the environment, whereas residents and environmentalists participating in the process presented a globalizing representation of it. The study has also highlighted the existence of different views in civil society, although they completed one another and converged into a critical view of the venture.

Results have shown that the study of social representations involved in the conflict could help identifying social actors' different motivations and goals. In addition, it enriched the analysis of the conflict and could be used as likely approach in future studies conducted in the environmental licensing field. So far, studies available in the literature mostly use this tool in the education field (SILVA, 2009); however, socio-environmental conflicts are a likely knowledge field to explore this approach.

\section{Acknowledgments}

This study was financed in part by the Coordenação de Aperfeiçoamento de Pessoal de Nível Superior - Brasil (CAPES) - Finance Code 001. We also would like to thank the Paranapiacaba residents and the SOS Paranapiacaba movement for participating in the research. 


\section{References}

ABRIC, J.C. (1993) Central system, peripheral system: their functions and roles in the dynamics of social representations. Papers on Social Representations, v. 2, n. 2, p. 75-78. 1993.

ACSELRAD, H. (Org.). Conflitos ambientais no Brasil. Rio de Janeiro: Relume Dumará: Fundação Heinrich Böll. 167 p. 2004.

BACIC, M. C.; OGAWA, N. R.; VIDAL, M. P. Estado da arte da pesquisa sobre conflitos ambientais - dissertações e teses do banco EArte. Encontro Nacional de Pesquisa em Educação em Ciências, 11, 2017. Florianópolis. Anais... Florianópolis: Universidade Federal de Santa Catarina, Florianópolis, v. 6, 2017.

BELLO, V. G. Gestão sustentável da paisagem cultural: legados e lições da experiência de Paranapiacaba. Revista CPC, n. 18, p. 29-55. 2014.

BERNARDELLI JÚNIOR, J. M.; RUIZ, M. S.; GALLARDO, A. M. C. F. Conflitos socioambientais na APA Bororé-Colônia: dos preexistentes aos novos associados ao licenciamento ambiental do trecho Sul do Rodoanel de São Paulo. Desenvolvimento em questão, v. 15, n. 40, p. 104-139. 2017.

BRONZ, D. Nos bastidores do licenciamento ambiental: uma etnografia das práticas empresariais em grandes empreendimentos. Rio de Janeiro: Contra Capa. 474 p. 2016.

COLANTUONO, A. C. S.; CESTARO, N. G. Paranapiacaba: dinâmica econômica em função de seus eventos. Revista Grifos, n. 42, p. 130-163. 2017.

CONSULTORIA, PLANEJAMENTO E ESTUDOS AMBIENTAIS LTDA - CPEA. Estudo de Impacto Ambiental do Centro Logístico Campo Grande. 2017a.

CONSULTORIA, PLANEJAMENTO E ESTUDOS AMBIENTAIS LTDA - CPEA. Relatório de Impacto Ambiental do Centro Logístico Campo Grande. 2017b.

CRESWELL, J. W. Projetos de pesquisa: método qualitativo, quantitativo e misto. Porto Alegre: Artmed, 2010.

FLEURY, L. C.; ALMEIDA, J. P. A conservação ambiental como critério de relações entre grupos e valores: representações e conflitos no entorno do Parque Nacional das Emas, Goiás. Ambiente \& Sociedade, v. 12, n. 2, p. 357-372, 2009.

GHOZ, N. C. C. E.; PIRES, P. T. L.; FEILSTRECKER, M. Ferramenta de programação neurolinguística para intermediação de conflitos ambientais. Revista Ibero-Americana de Ciências Ambientais, v.11, n.4, 2020.

GLUNCKER, A. N.; DRILSSEN, P. P. J.; KOLHOFF, A.; RUNHAAR, H. A. C. Public participation in environmental impact assessment: why, who and how? Environmental Impact Assessment Review, n. 43, 2013. 
JODELET, D. Representações sociais: um domínio em expansão. As representações sociais, v. 17 , p. 14-44, 2001.

LOUREIRO, C. F. B.; LIMA, M. J. G. S. A hegemonia do discurso empresarial de sustentabilidade nos projetos de educação ambiental no contexto escolar: nova estratégia do capital. Revista Contemporânea de Educação, v. 7, n. 14. 2012.

MATOS, F. R. N.; IPIRANGA, A. S. R.; MACHADO, D. Q.; ROLIM, G. F.; ALVARENGA, R. A. M. Representações sociais e sustentabilidade: o significado do termo para alunos do curso de administração. Administração: Ensino e Pesquisa, Rio de Janeiro, v. 13, n. 4, p. 707-734, 2012.

MELO, A. Centro logístico ignora Justiça e segue processo de licenciamento. Diário do Grande ABC, 18 out. 2019. Setecidades. Disponível em: https://www.dgabc.com.br/Noticia/3147589/ centro-logistico-ignora-justica-e-segue-processo-de-licenciamento. Access on April 7th, 2021.

MOSCOVICI, S. A representação social da psicanálise. Rio de Janeiro, Zahar, 1978.

NASCIMENTO-SCHÜLZE, C. M. Representações sociais da natureza e do meio ambiente. Revista de Ciências Humanas, Edição Especial Temática, p. 67-81, 2000.

NETO, M. M. Protagonismo comunitário em Paranapiacaba: o impacto das ações governamentais no desenvolvimento socioeconômico-comunitário da Vila de Paranapiacaba no período de 2001 a 2004. 2005. Dissertação (Mestrado em Administração). Universidade Municipal de São Caetano Do Sul, São Caetano do Sul.

PEREZ, M. Grandezas e medidas: representações sociais de professores do ensino fundamental. 2008. 201 f. Curitiba. Tese (Doutorado em Educação) - Universidade Federal do Paraná, 2008.

POLLI, G. M.; KUHNEN, A. Possibilidades de uso da teoria das representações sociais para os estudos pessoa-ambiente. Estud. psicol., Natal, v.16, n.1, 2011.

RAMOS, F. A.; KAWAMURA, M. R. D. Representações sobre sustentabilidade: contribuições para a abordagem de questões ambientais. Encontro Nacional de Pesquisa em Educação em Ciências, Florianópolis, v. 7, 2009.

REIGOTA, M. Meio Ambiente e Representação Social. São Paulo: Cortez, 5ª ed., 2002.

ROSA, R.E. Os conflitos socioambientais à luz de uma articulação teórica entre Pierre Bourdieu e Serge Moscovici. Àskesis, v. 3, n. 2, 2014.

SÁ, C. P. Representações sociais: teoria e pesquisa do núcleo central. Temas em Psicologia, Rio de Janeiro, n.3, p. 19-31, 1996.

SANT'ANNA, H. C. OpenEvoc: Um programa de apoio à pesquisa em Representações Sociais. Revista Psicologia Social: Desafios Contemporâneos. Espírito Santo, p. 94-103, 2012.

SANTOS, S. L.; CHESS, C. Evaluating citizen advisory boards: the importance of theory and 
participant-based criteria and practical implications. Risk Analysis, v. 23, n. 2, 2003.

SILVA, S. N. Concepções e representações sociais de Meio Ambiente: Uma revisão crítica da literatura. Encontro Nacional de Pesquisa em Educação em Ciências, Florianópolis, v. 7, 2009.

SOUSA, D. R. N.; OLIVEIRA, M. R. L.; FONSECA, B. C. Conflitos ambientais: uma análise da assimetria de poder entre os atores sociais envolvidos no caso do Mineroduto da Ferrous. Sociedade e Natureza, Uberlândia, v. 27, n. 3, p. 405-420. 2015.

SOUZA FILHO, E. A.; DURANDEGUI, A. B. Representações sociais sobre o meio ambiente entre ecologistas ligados a ONGs no Brasil. Revista de Ciências Humanas, Florianópolis, n. 32, p. 265-292, out. 2002.

TECHIO, E. M.; GONÇALVES, J. P.; COSTA, P. N. Representação social da sustentabilidade na construção civil: a visão de estudantes universitários. Ambiente $\mathbb{\&}$ Sociedade, São Paulo, v. 19, n. 2, p. 187-204, jun. 2016.

TORRES; P. H. C.; RAMOS, R. F.; GONÇALVES, L. S. Conflitos ambientais na Macrometrópole Paulista: Paranapiacaba e São Sebastião. Ambiente \& Sociedade, São Paulo, v. 22, 2019.

TOSSATO, D. TJ-SP libera construção do porto seco em Paranapiacaba. Diário do Grande ABC. 20 fev. 2021. Política. Disponível em: https://www.dgabc.com.br/Noticia/3681263/tj-sp-libera-construcao-do-porto-seco-em-paranapiacaba. Access on April 7th, 2021.

WESTMAN, W. E. Ecology, impact assessment, and environmental planning. Wiley, 532 p. 1985.

WOLTER, R. P.; GURRIERI, C.; SORRIBAS, E. Empirical illustration of the hierarchical organisation of social thought: a domino effect? Interamerican Journal of Psychology, v. 43, n. 1, 2009. 
Virgínia Hamer Campagnaro

vhcampagnaro@hotmail.com

ORCiD: https://orcid.org/0000-0002-9680-2440
Submitted on: 05/11/2020

Accepted on: 07/07/2021

2021;24e:02121

\section{Luciana Aparecida Farias}

凹luciana.farias@unifesp.br

ORCiD: https://orcid.org/0000-0003-3343-3403

\section{Giovano Candiani}

घcandiani@unifesp.br

ORCiD: http://orcid.org/0000-0001-9896-4390

How to cite: CAMPAGNARO, V. H.; FARIAS, L. A.; CANDIANI, G. Socio-environmental conflicts: a study on the Logistic Center in Paranapiacaba and involved social representations. Ambiente \& Sociedade. São Paulo, v. 24, p. 1-21, 2021. 


\title{
Conflitos Socioambientais: um Estudo Sobre o Centro Logístico em Paranapiacaba e as Representações Sociais Envolvidas
}

\author{
Virgínia Hamer Campagnaro \\ Luciana Aparecida Farias \\ Giovano Candiani
}

São Paulo. Vol. 24, 2021

Artigo Original
Resumo: Os conflitos socioambientais vêm se intensificando no século XXI, de maneira que novas abordagens têm sido utilizadas para estudá-los, buscando identificar sua origem e enriquecer suas análises. O presente estudo objetivou acompanhar o licenciamento ambiental do Centro Logístico Campo Grande, em Paranapiacaba, município de Santo André (SP), identificando as representações sociais de meio ambiente dos atores envolvidos e discutindo sua interferência no conflito estabelecido. $\mathrm{O}$ estudo de caso foi baseado em método misto, levantando dados por observação participante, entrevista estruturada e análise documental. Foi realizada uma análise prototípica segundo teoria das representações sociais de Moscovici, Abric e classificação de Reigota para meio ambiente. As representações sociais encontradas foram globalizante para a sociedade civil e antropocêntrica para o empreendedor, relacionando a origem do conflito às diferentes apropriações materiais e simbólicas dos recursos ambientais, no caso, o território.

Palavras-chave: Conflito Socioambiental; Representações Sociais; Paranapiacaba; Participação Pública; Licenciamento Ambiental.

Como citar: CAMPAGNARO, V. H.; FARIAS, L. A.; CANDIANI, G. Conflitos Socioambientais: um estudo sobre o Centro Logístico em Paranapiacaba e as representações sociais envolvidas. . Ambiente $\mathbb{\&}$ Sociedade. São Paulo, v. 24, p. 1-21, 2021. 


\title{
Conflictos Socioambientales: un Estudio Sobre el Centro Logístico en Paranapiacaba y las Representaciones Sociales Involucradas
}

\author{
Virgínia Hamer Campagnaro \\ Luciana Aparecida Farias \\ Giovano Candiani
}

São Paulo. Vol. 24, 2021

Artículo original
Resumen: Los conflictos socioambientales se han ido intensificando en el siglo XXI, por lo que se han utilizado nuevos enfoques que buscan identificar el origen de estos conflictos y enriquecer sus análisis. El presente estudio tuvo como objetivo monitorear el licenciamiento ambiental del Centro Logístico Campo Grande, en Paranapiacaba, municipio de Santo André (SP), para identificar las representaciones sociales del medio ambiente de los actores involucrados y evaluar como las representaciones interfirieron en el conflicto establecido. El estudio de caso se basó en un método mixto, mediante el cual se recopilaron datos a través de la observación participante, la entrevista estructurada y el análisis de documentos. Se realizó un análisis prototípico acorde con la teoría de las representaciones sociales de Moscovici, Abric y la clasificación de Reigota para el medio ambiente. Las representaciones sociales encontradas fueron globalizadoras para la sociedad civil y antropocéntricas para el emprendedor, lo cual relaciona el origen del conflicto con diferentes apropiaciones materiales y simbólicas de los recursos ambientales, en este caso, el territorio.

Palabras-clave: Conflicto socioambiental; Representaciones sociales; Paranapiacaba; Participación pública; Licenciamiento Ambiental.

Como citar: Conflictos socioambientales: un estudio sobre el Centro Logístico en Paranapiacaba y las representaciones sociales involucradas. Ambiente \& Sociedade. São Paulo, v. 24, p. 1-21, 2021.

DOI: http://dx.doi.org/10.1590/1809-4422asoc20200212r1vu2021L4AO 